\title{
Implementation of state-of-the-art ternary new-particle formation scheme to the regional chemical transport model PMCAMx-UF in Europe
}

Elham Baranizadeh ${ }^{1}$, Benjamin N. Murphy ${ }^{2, a}$, Jan Julin ${ }^{1,2}$, Saeed Falahat ${ }^{2, b}$, Carly L. Reddington ${ }^{3}$, Antti Arola Lars Ahlm $^{2}$, Santtu Mikkonen ${ }^{1}$, Christos Fountoukis ${ }^{5}$, David Patoulias ${ }^{6}$, Andreas Minikin ${ }^{7, c}$, Thomas Hamburger ${ }^{8, d}$, Ari Laaksonen ${ }^{1,9}$, Spyros N. Pandis ${ }^{6,10,11}$, Hanna Vehkamäki ${ }^{12}$, Kari E. J. Lehtinen ${ }^{1,4}$, and Ilona Riipinen ${ }^{2}$

${ }^{1}$ Aerosol Physics Group, Department of Applied Physics, University of Eastern Finland, Kuopio, Finland

${ }^{2}$ Department of Environmental Science and Analytical Chemistry (ACES), Stockholm University, Stockholm, Sweden

${ }^{3}$ Institute for Climate and Atmospheric Science, School of Earth and Environment, University of Leeds, Leeds, UK

${ }^{4}$ Atmospheric Research Centre of Eastern Finland, Finnish Meteorological Institute, Kuopio, Finland

${ }^{5}$ Qatar Environment and Energy Research Institute (QEERI), Hamad Bin Khalifa University (HBKU), Qatar Foundation, Doha, Qatar

${ }^{6}$ Department of Chemical Engineering, University of Patras, Patras, Greece

${ }^{7}$ Deutsches Zentrum für Luft- und Raumfahrt (DLR), Institut für Physik der Atmosphäre, Oberpfaffenhofen, Germany

${ }^{8}$ Atmosphere and Climate Department (ATMOS), Norwegian Institute for Air Research (NILU), Oslo, Norway

${ }^{9}$ Climate research Unit, Finnish Meteorological Institute, Helsinki, Finland

${ }^{10}$ Institute of Chemical Engineering Sciences, Foundation for Research and Technology Hellas (ICEHT/FORTH),

Patras, Greece

${ }^{11}$ Department of Chemical Engineering, Carnegie Mellon University, Pittsburgh, PA, USA

${ }^{12}$ Division of Atmospheric Sciences, Department of Physics, University of Helsinki, Helsinki, Finland

${ }^{a}$ now at: the National Exposure Research Laboratory, US Environmental Protection Agency, Research Triangle Park, Durham, NC, USA

b now at: the Swedish Meteorological and Hydrological institute (SMHI), Norrköping, Sweden

${ }^{c}$ now at: Deutsches Zentrum für Luft- und Raumfahrt (DLR), Flugexperimente, Oberpfaffenhofen, Germany

${ }^{d}$ now at: Federal Office for Radiation Protection (BfS), Neuherberg, Germany

Correspondence to: Ilona Riipinen (ilona.riipinen@aces.su.se)

Received: 27 January 2016 - Published in Geosci. Model Dev. Discuss.: 11 February 2016

Revised: 23 June 2016 - Accepted: 18 July 2016 - Published: 22 August 2016

\begin{abstract}
The particle formation scheme within PMCAMxUF, a three-dimensional chemical transport model, was updated with particle formation rates for the ternary $\mathrm{H}_{2} \mathrm{SO}_{4}-$ $\mathrm{NH}_{3}-\mathrm{H}_{2} \mathrm{O}$ pathway simulated by the Atmospheric Cluster Dynamics Code (ACDC) using quantum chemical input data. The model was applied over Europe for May 2008, during which the EUCAARI-LONGREX (European Aerosol Cloud Climate and Air Quality Interactions-Long-Range Experiment)campaign was carried out, providing aircraft vertical profiles of aerosol number concentrations. The updated model reproduces the observed number concentrations
\end{abstract}

of particles larger than $4 \mathrm{~nm}$ within 1 order of magnitude throughout the atmospheric column. This agreement is encouraging considering the fact that no semi-empirical fitting was needed to obtain realistic particle formation rates. The cloud adjustment scheme for modifying the photolysis rate profiles within PMCAMx-UF was also updated with the TUV (Tropospheric Ultraviolet and Visible) radiativetransfer model. Results show that, although the effect of the new cloud adjustment scheme on total number concentrations is small, enhanced new-particle formation is predicted near cloudy regions. This is due to the enhanced radiation 
above and in the vicinity of the clouds, which in turn leads to higher production of sulfuric acid. The sensitivity of the results to including emissions from natural sources is also discussed.

\section{Introduction}

Formation of new particles from atmospheric vapors (newparticle formation, NPF) is potentially an important source of particulate matter in the atmosphere, especially in the ultrafine $(<100 \mathrm{~nm}$ in diameter) size range (Kulmala et al., 2004; Merikanto et al., 2009; Jung et al., 2010; Fountoukis et al., 2012; Kerminen et al., 2012; Fuzzi et al., 2015). In the past, in modeling studies on the role of in situ NPF as a particle source, particle formation has been represented with various parameterizations including binary (Vehkamäki et al., 2002) or ternary (Napari et al., 2002) nucleation based on the classical nucleation theory (CNT), semi-empirical activation (Kulmala et al., 2006), kinetic (McMurry, 1980) or organic-enhanced (Paasonen et al., 2010) NPF, and/or ionmediated nucleation (Yu and Luo, 2009). These parameterizations have generally assumed sulfuric acid $\left(\mathrm{H}_{2} \mathrm{SO}_{4}\right)$, water $\left(\mathrm{H}_{2} \mathrm{O}\right)$, ammonia $\left(\mathrm{NH}_{3}\right)$, or different organic species as the compounds forming the new particles. The activation, kinetic, and organic-enhanced mechanisms are semi-empirical, based on the observed dependence of particle formation rates on concentrations of sulfuric acid and/or organic vapors ( $\mathrm{Si}$ hto et al., 2006; Paasonen et al., 2010). The advantage of such methods is that they are simple and produce nucleation rates of the same order as those observed. However, as they are fit to specific experiments usually at ground level, they are most reliable at locations and conditions similar to those at which the data have been obtained. The ternary $\mathrm{H}_{2} \mathrm{SO}_{4}-$ $\mathrm{H}_{2} \mathrm{O}-\mathrm{NH}_{3}$ parameterization by Napari et al. (2002) has been used with some success (Jung et al., 2008, 2010; Fountoukis et al., 2012; Westervelt et al., 2014) but with quite drastic correction factors necessary to reproduce ambient particle number concentrations. In many previous studies (Spracklen et al., 2006; Makkonen et al., 2009; Yu et al., 2010) the binary $\mathrm{H}_{2} \mathrm{SO}_{4}-\mathrm{H}_{2} \mathrm{O}$ nucleation has been assumed to dominate in the upper atmosphere and be negligible at lower altitudes, and it has often been superimposed with one of the other mechanisms.

Sulfuric acid, water, and ammonia have long been established as important molecules forming new particles in the atmosphere (Korhonen et al., 1999; Kulmala et al., 2000; Laaksonen et al., 2008). However, standard theoretical descriptions of the ternary $\mathrm{H}_{2} \mathrm{SO}_{4}-\mathrm{H}_{2} \mathrm{O}-\mathrm{NH}_{3}$ particle formation pathway have not been able to reproduce measured particle formation rates - hence the need to resort to semi-empirical parameterizations and correction factors to describe this process in atmospheric models. Recent experimental (Kirkby et al., 2011; Almeida et al., 2013; Jen et al., 2014) and com- putational developments have, however, changed this picture drastically. Flexible computational models (such as the Atmospheric Cluster Dynamics Code, ACDC; Olenius et al., 2013) which simulate the kinetics of a population of molecular clusters combined with cluster free energies calculated from first-principles methods, can now reproduce laboratory observations of particle formation rates in $\mathrm{H}_{2} \mathrm{SO}_{4}-\mathrm{NH}_{3}$ as well as sulfuric acid-amine systems with reasonable accuracy (Almeida et al., 2013), without the need for empirical scaling of the predicted particle formation rate.

Predictions of particle number concentration from regional-scale chemical transport models have been evaluated typically with data from ground-level observations (Jung et al., 2008; Matsui et al., 2011, 2013; Fountoukis et al., 2012; Cui et al., 2014; Lupascu et al., 2015). Meanwhile, there is much to gain from assessing the model against vertically resolved particle number observations, as many of the uncertainties in the model relate to particle scavenging, by hydrometeors as well as other particles, and mixing of air masses. The possible biases introduced from parameterizing new-particle formation rates with ground-level data makes it all the more imperative to evaluate and constrain models with observations taken at altitude. Recent studies (Reddington et al., 2011; Matsui et al., 2013; Lupascu et al., 2015) have begun assessing global- and regional-scale models in this way against data from European, Asian and US field campaigns involving aircraft measurements. Furthermore, it is worthwhile to explore the vertical variability in chemical and environmental precursors to NPF (e.g., $\mathrm{H}_{2} \mathrm{SO}_{4}, \mathrm{NH}_{3}, T$, relative humidity $(\mathrm{RH})$ ) and particle number concentrations.

In this work we describe the implementation of a $\mathrm{H}_{2} \mathrm{SO}_{4}-$ $\mathrm{H}_{2} \mathrm{O}-\mathrm{NH}_{3}$ new-particle formation scheme based on the output of the ACDC model to the regional chemical transport model PMCAMx-UF (Jung et al., 2010; Fountoukis et al., 2012). We test the new scheme by simulating the evolution of atmospheric gas-phase and aerosol particle concentrations during May 2008 in Europe. We evaluate the model against ground-based and airborne observations of aerosol particle number size distributions during the simulated period. Furthermore, we implement an updated radiativetransfer scheme TUV (Tropospheric Ultraviolet and Visible radiative-transfer model; Madronich, 2002) for PMCAMxUF and discuss its implications for predictions of NPF and particle number concentrations in the European domain.

\section{Methods}

\subsection{PMCAMx-UF model description}

PMCAMx-UF is a three-dimensional regional chemical transport model that simulates both the size-dependent particle number and chemically resolved mass concentrations (Jung et al., 2010). PMCAMx-UF utilizes the framework of the air quality model PMCAMx (Gaydos et al., 2007; Kary- 
dis et al., 2007), where the description of vertical and horizontal advection and dispersion, wet and dry deposition, and gas-phase chemistry are based on the Comprehensive Air Quality Model with Extensions (CAMx) air quality model, and the variable size-resolution model of Fahey and Pandis (2001) is used for aqueous-phase chemistry. To treat the aerosol microphysics - including NPF, condensation, and coagulation - PMCAMx-UF uses the Dynamic Model for Aerosol Nucleation (DMAN) module by Jung et al. (2006). DMAN uses the Two-Moment Aerosol Sectional (TOMAS) algorithm (Adams and Seinfeld, 2002) to track the aerosol number and mass distributions. DMAN divides the aerosol particles into 41 logarithmically spaced size bins between $0.8 \mathrm{~nm}$ and $10 \mu \mathrm{m}$.

The aerosol species modeled in PMCAMx-UF include sulfate, ammonium, water, elemental carbon, crustal material, chloride, sodium, nitrate, primary organic aerosol and four secondary organic aerosol surrogate compounds. The version of TOMAS used in the model applied here tracks explicitly the mass transfer of sulfate and ammonium, while that of water is treated assuming equilibrium. Within the DMAN aerosol microphysics module the remaining compounds are represented by inert surrogate species. The pseudo-steady-state approximation method (Pierce and Adams, 2009), which assumes steady-state concentration for sulfuric acid, is used for the calculation of NPF and sulfuric acid condensation rates. The condensation of ammonia is calculated independently following the approach described in Jung et al. (2006).

New-particle formation rates in the standard version of PMCAMx-UF have been calculated in previous studies using a scaled version of the ternary $\mathrm{H}_{2} \mathrm{SO}_{4}-\mathrm{NH}_{3}-\mathrm{H}_{2} \mathrm{O}$ parametrization by Napari et al. (2002), hereafter referred to as the "scaled" Napari parameterization. The original Napari parameterization is based on predictions of the CNT assuming that the energetics of the molecular clusters follow bulk thermodynamics. While it has been shown to perform better than a range of other nucleation parameterizations in predicting the occurrence of new-particle formation events (Jung et al., 2008), it is also known to overpredict ultrafine particle number concentrations (Gaydos et al., 2005; Yu, 2006; Jung et al., 2006; Merikanto et al., 2007b; Zhang et al., 2010). Thus a semi-empirical correction factor of $10^{-6}$ has been applied previously in PMCAMx-UF to scale the formation rates produced by the Napari parameterization and better match the observations (Jung et al., 2010; Fountoukis et al., 2012; Ahlm et al., 2013). It should be noted that, due to an unfortunate coding error in the implementation of the scaled Napari parameterization in the DMAN module, the scaled Napari scheme has operated in PMCAMx-UF without temperature or RH dependence. This is also the case for the runs using scaled Napari in the present paper, as these have been performed to facilitate comparison with previous works.

Encouraged by the good agreement between particle formation rates predicted by the ACDC model and the state- of-the-art experimental data (Almeida et al., 2013), we have updated the particle formation scheme within PMCAMxUF with ACDC-based particle formation rates for the $\mathrm{NH}_{3}-$ $\mathrm{H}_{2} \mathrm{SO}_{4}-\mathrm{H}_{2} \mathrm{O}$ (see Sect. 2.2 for details and the Results section for comparison to the scaled Napari parameterization). In addition to applying the ternary $\mathrm{H}_{2} \mathrm{SO}_{4}-\mathrm{NH}_{3}-\mathrm{H}_{2} \mathrm{O} \mathrm{NPF}$ scheme, we also include a binary $\mathrm{H}_{2} \mathrm{SO}_{4}-\mathrm{H}_{2} \mathrm{O}$ NPF pathway. This pathway is operating simultaneously with the ternary pathway and is based on the Vehkamäki et al. (2002) CNT parameterization.

PMCAMx-UF was applied for the period of May 2008 for the European domain, which consists of a $5400 \times 5832 \mathrm{~km}^{2}$ region with a $36 \times 36 \mathrm{~km}^{2}$ grid resolution and 14 vertical layers reaching an altitude of approximately $20 \mathrm{~km}$. The PMCAMx-UF output data are hourly averaged. The meteorological inputs, described in detail in Fountoukis et al. (2011, 2012), were created using the Weather Research and Forecasting model version 2 (Skamarock et al., 2005) and include horizontal wind components, vertical dispersion coefficients, temperature, pressure, water vapor mixing ratios, cloud optical depths and rainfall rates. Hourly gridded emissions include anthropogenic emission rates of primary particulate matter and gases. For the particle emissions the pan-European anthropogenic particle number emission inventory (Denier van der Gon et al., 2009; Kulmala et al., 2011) and the pan-European carbonaceous aerosol inventory (Kulmala et al., 2011) were used. The anthropogenic gas emissions include both land emissions from the GEMS (Global and regional Earth-system Monitoring using Satellite and in situ data) data set (Visschedijk et al., 2007) and international shipping emissions. These emission inputs are the same as have been used previously for the May 2008 period in PMCAMx-UF (in Fountoukis et al., 2012; Ahlm et al., 2013), and thus in order to enable comparison to the previous works these inputs are used in all of the base model runs of the present paper. To assess how much the particle number concentrations are affected by emissions from natural sources, we have performed simulations with and without these emissions. The natural emissions include both particulate matter and gases and combine three different data sets: emissions from ecosystems based on the Model of Emissions of Gases and Aerosols from Nature (MEGAN; Guenther et al., 2006), marine emissions based on the model of O'Dowd et al. (2008), and wildfire emissions (Sofiev et al., 2008a, b).

\subsection{Improved treatment of the ternary NPF pathway}

The ternary $\mathrm{H}_{2} \mathrm{SO}_{4}-\mathrm{NH}_{3}-\mathrm{H}_{2} \mathrm{O}$ particle formation rate at approximately $1.3 \mathrm{~nm}$ in mobility diameter was calculated with the ACDC (Olenius et al., 2013; Almeida et al., 2013; Henschel et al., 2016). ACDC simulates the dynamics of a population of molecular clusters by numerically solving the cluster birth-death equations. Instead of considering only collisions and evaporations of single vapor molecules, an oftenused assumption applied in the CNT framework, ACDC 
allows all possible collision and fragmentation processes within the cluster population. As input the ACDC code needs the corresponding rate constants, of which the most challenging to assess are the cluster evaporation rates, generally calculated from the free energies of formation of the clusters. The evaporation rates play a significant role in determining the number concentration and consequently the formation rate of small particles. The liquid drop model, commonly used in CNT to calculate the free energies of cluster formation, is based on macroscopic thermodynamics and is thus not expected to give reliable results for small clusters (Merikanto et al., 2007a). Among the most important of additional uncertainties is representing the energetics of the system with bulk thermodynamics, e.g., assuming complete proton transfer, which is known not to hold for small clusters and results in drastic errors in the formation free energies and internally inconsistent handling of small stable ammoniasulfuric acid clusters. The most accurate theoretical method to compute the free energies of clusters consisting of specific molecules is quantum chemistry. This modeling approach is able to reproduce the general trends in cluster formation and leads to, thus far, the best quantitative agreement between observations and modeling with no fitting parameters (Almeida et al., 2013). Having a description that has been evaluated against laboratory data and has, e.g., temperature and $\mathrm{RH}$ dependencies in line with the current theoretical understanding gives a new capacity for, e.g., extrapolating back to the pre-industrial atmosphere for which we have very little observational data (see, e.g., Carslaw et al., 2013; Kirkby et al., 2016).

In the ACDC simulations of this work, hard-sphere collision rates were used for the collision rate coefficients, and the evaporation rate coefficients were calculated from the Gibbs free energies of formation of the clusters computed with quantum chemical methods at the B3LYP/CBSB7//RICC2/aug-cc-pV(T+d)Z level (Ortega et al., 2012; Henschel et al., 2014). This level of theory has been tested against higher-level methods and was shown to give reliable cluster formation free energies at an affordable computational cost. The simulation included clusters containing up to three $\mathrm{H}_{2} \mathrm{SO}_{4}$ and three $\mathrm{NH}_{3}$ molecules, hydrated by up to four or five water molecules. Sulfuric acid and ammonia were explicitly treated in the simulation, and water was implicitly included by assuming that the clusters are in equilibrium with respect to water and by using hydrate averaged collision and evaporation rates. An external sink term corresponding to scavenging by larger particles was used for all the clusters. The steady-state particle formation rate was obtained as the flux of clusters growing out of the simulation system considering boundary conditions based on cluster stability. Details of the simulated ternary $\mathrm{H}_{2} \mathrm{SO}_{4}-\mathrm{NH}_{3}-$ $\mathrm{H}_{2} \mathrm{O}$ system can be found in Henschel et al. (2016).

The ACDC results were implemented in the PMCAMxUF framework as a lookup table consisting of a comprehensive set of particle formation rates computed at different values of $\mathrm{H}_{2} \mathrm{SO}_{4}$ and $\mathrm{NH}_{3}$ concentrations, temperature, $\mathrm{RH}$, and coagulational loss rate due to scavenging by the population of larger particles (described by the condensation sink; see, e.g., Dal Maso et al., 2002). The formation rate data produced by theoretical models have been traditionally fitted to a multivariable functional form (Napari et al., 2002; Merikanto et al., 2007b), with the resulting parameterization then utilized by large-scale models. However, finding a suitable functional form to cover satisfactorily the whole parameter space becomes increasingly difficult with increasing number of input parameters; with increasing number of species participating in NPF; and with the tendency of formation rates to exhibit rapid, step-function-like changes with respect to one or more parameters. Thus interpolating from a lookup table provides formation rates that are more closely in line with the original theoretical model, with a relatively minor additional computational cost. The parameter space encompasses sulfuric acid concentration between $1.00 \times 10^{4}$ and $3.16 \times 10^{9}$ molecules $\mathrm{cm}^{-3}$, ammonia concentration between $10^{6}$ and $10^{11}$ molecules $\mathrm{cm}^{-3}$, relative humidity between 0 and $100 \%$, temperature between 180 and $320 \mathrm{~K}$, and condensation sink between $10^{-5}$ and $10^{-1} \mathrm{~s}^{-1}$. These conditions bound the environmental and chemical conditions predicted by typical PMCAMx-UF runs for Europe in May. PMCAMx-UF uses multilinear interpolation to extract formation rates from the lookup table. The newly formed particles are added to the second-lowest size bin of PMCAMxUF, corresponding to the size for which the ACDC formation rates were calculated. This approach provides PMCAMx-UF with formation rates that are based on the full kinetic treatment of the cluster population.

\subsection{Radiative-transfer and photolysis rates}

Aerosols and clouds can enhance or reduce photolysis of relevant gas-phase chemical species in the atmosphere by reflecting, scattering, or absorbing solar radiation. Modifications of photolysis rates via this interaction lead to changes in the production rate of sulfuric acid, which lead directly to changes in the new-particle formation rates. Previous versions of PMCAMx-UF employed a parameterization originally used by the Regional Acid Deposition Model (RADM; Chang et al., 1987) to treat the modification of photolysis rates due to cloud presence. This approach required the cloud optical depth from the meteorological input data and the solar zenith angle in order to calculate the time- and layerdependent adjustment factors for the photolysis rates. This method, however, did not use aerosol concentrations predicted online by the transport model. Instead, a reference aerosol profile was used for every time step and column of grid cells.

To more realistically treat the effects of clouds on the photolysis rates profile of the atmospheric column, we updated the online approach in PMCAMx-UF to a streamlined form of the two-stream radiative-transfer module, TUV 
(Madronich, 2002). The implementation of TUV was completed as documented by Emery et al. (2010). This simplified module employs a reduced number of wavelength bands and plane-parallel two-stream approximations. Inputs needed include the cloud optical depth, solar zenith angle, threedimensional aerosol concentration profile, and optical properties of the aerosol components provided by Takemura et al. (2002).

The total cloud optical depth $\tau$ above a current grid cell to the top of troposphere is approximated offline by

$\tau=\frac{3 L \Delta z_{\mathrm{c}}}{2 \rho_{\mathrm{W}} r}$,

where $L$ is the mean cloud liquid water $\left(\mathrm{g} \mathrm{m}^{-3}\right), \Delta z_{\mathrm{c}}$ is the mean depth of cloudy layer $(\mathrm{m})$ in the cell, $\rho$ is the density of water $\left(10^{6} \mathrm{~g} \mathrm{~m}^{-3}\right)$, and $r$ is the mean cloud-drop radius $\left(10^{-5} \mathrm{~m}\right)$. The module also uses the time- and spacedependent vertical profile of dry and wet (with an RHdependent lensing effect) aerosols predicted by PMCAMxUF.

The module outputs a modified actinic flux that can then be applied, using the clear-sky actinic flux for reference, to adjust the clear-sky photolysis rates. Adjustments due to clouds and aerosols tend to reduce photolysis below clouds but often enhance rates above clouds because of the reflection from the top of the cloud. Emery et al. (2010) implemented the module in CAMx and evaluated it for ozone prediction in the Houston area. That study found decreased ozone surface concentrations with maximum decreases of approximately $10 \mathrm{ppb}$. However, they did not report the impacts that the radiation feedback would have on particulate mass or number. We compare particle number and sulfuric acid vapor profiles with and without the radiation update in place to better understand the importance of correctly representing this phenomenon.

\subsection{Model evaluation with particle number and size distribution data}

During the European Aerosol Cloud Climate and Air Quality Interactions (EUCAARI) project (Kulmala et al., 2009, 2011) particle number size distributions within the atmospheric boundary layer were measured at various European Supersites for Atmospheric Aerosol Research (EUSAAR). May 2008 was one of the intensive observation periods of the project. In this study the predicted ground-level hourly averaged particle number concentrations are evaluated against the data from Aspvreten (Sweden), Cabauw (Netherlands), Hyytiälä (Finland), Ispra (Italy), Mace Head (Ireland), Melpitz (Germany), and Vavihill (Sweden) similarly to Fountoukis et al. (2012). These locations represent seven different types of European environments (Ahlm et al., 2013). More information about the characteristics and topography of these sites is available elsewhere (Asmi et al., 2011; Fountoukis et al., 2012). The particle size distribution measurements were carried out using either a differential mobility particle sizer (DMPS) or scanning mobility particle sizer (SMPS) systems in the mobility diameter size range above $10 \mathrm{~nm}$.

To evaluate the vertical profile of the particle size distribution, we used the observational data measured by the German DLR Falcon 20 and the British FAAM (Facility for Airborne Atmospheric Measurements) BAe-146 research aircrafts, operating between 6 and 24 May 2008. The aircraft data were collected during the Long-Range Experiment (LONGREX) campaign (Hamburger et al., 2011), which was also a part of the EUCAARI project. The FAAM BAe-146 flights mainly flew in the boundary layer and lower free troposphere, while the DLR Falcon 20 aircraft mostly probed the free troposphere up to the tropopause level (Hamburger et al., 2011). The Condensation Particle Size Analyzer (CPSA) (Fiebig et al., 2005; Feldpausch et al., 2006), installed aboard the DLR Falcon 20, and the Passive Cavity Aerosol Spectrometer Probe (PCASP-100X) (Liu et al., 1992), operated aboard both aircraft, measured the particle number concentrations. Consistent with Reddington et al. (2011), we used the measurements from two channels of the CPSA aboard the DLR Falcon 20 with lower cut-off diameters of 4 and $10 \mathrm{~nm}$, yielding the number concentrations of particles above these sizes, denoted as $N_{4}$ and $N_{10}$. The temporal resolution of the CPSA data set is $1 \mathrm{~s}$. The nominal size range of PCASP-100X is $0.12-3.5 \mu \mathrm{m}$ with 15 channels. The PCASP-100X raw data were sampled with $1 \mathrm{~Hz}$ frequency, but the data used here are based on averaging over a constant interval of $5 \mathrm{~s}$. We used the measured particle number concentrations obtained from channels 3 to 10 of the PCASP-100X covering the diameter range of 160-1040 nm, representative of the accumulation mode, also to facilitate comparisons with the results reported by Reddington et al. (2011). We also used a TSI 3786 Condensation Particle Counter (CPC) aboard the FAAM BAe146 aircraft to measure the number concentrations of particles larger than $4 \mathrm{~nm}$.

A map of flight tracks by the Falcon 20 and BAe-146 and more details about EUCAARI-LONGREX data set are available elsewhere (Reddington et al., 2011; Hamburger et al., 2012). Measurements from the LONGREX campaign span altitudes corresponding to 13 of the 14 vertical layers of PMCAMx-UF (Fig. S1 in the Supplement). The model data were paired with the aircraft data by converting the timedependent latitude, longitude, and altitude of the plane to a model grid-cell index.

\section{Results}

\subsection{Surface-level particle number concentrations}

In this study we explore the sensitivity of PMCAMx-UF to cases (1) with an updated NPF scheme with ACDCbased formation rates, (2) with an updated cloud adjustment scheme with TUV implementation, and (3) including natural 
Table 1. Summary of PMCAMx-UF model simulations reported in this study. The arithmetic mean of ground-level number concentration during May 2008 for particles larger than $0.8 \mathrm{~nm}\left(N_{\mathrm{tot}}\right), 50 \mathrm{~nm}\left(N_{50}\right)$ and $100 \mathrm{~nm}\left(N_{100}\right)$ is given for each simulation.

\begin{tabular}{|c|c|c|c|c|c|c|}
\hline \multirow[t]{2}{*}{ Simulation name } & \multirow[t]{2}{*}{ NPF scheme } & \multirow[t]{2}{*}{$\begin{array}{l}\text { Cloud adjustment } \\
\text { scheme }\end{array}$} & \multirow[t]{2}{*}{ Emissions } & \multicolumn{3}{|c|}{$\begin{array}{l}\text { Domain mean number } \\
\text { concentration }\left(\mathrm{cm}^{-3}\right)\end{array}$} \\
\hline & & & & $N_{\text {tot }}$ & $N_{50}$ & $N_{100}$ \\
\hline ACDC-TUV-DE ${ }^{\mathrm{a}}$ & ACDC-based & TUV & Default & 59200 & 1300 & 360 \\
\hline ACDC-RADM-DE & ACDC-based & RADM & Default & 62000 & 1200 & 340 \\
\hline ACDC-TUV-NE ${ }^{\mathrm{b}}$ & ACDC-based & TUV & Updated & 48300 & 1300 & 380 \\
\hline Napari-TUV-DE & Scaled Napari et al. (2002) & TUV & Default & 8100 & 1500 & 410 \\
\hline Napari-RADM-DE & Scaled Napari et al. (2002) & RADM & Default & 9000 & 1500 & 400 \\
\hline
\end{tabular}

${ }^{a}$ DE: default emissions. The "default emissions" refer to the emissions used in Fountoukis et al. (2012; simulation Napari-RADM-DE). ${ }^{\text {b NE: new }}$ emissions, including natural emissions from biogenic, marine, and wildfire sources.

particle number emissions. The baseline simulation (hereafter ACDC-TUV-DE; see Table 1) represents a prediction of the particle number concentrations with implementation of ACDC-based NPF scheme and TUV cloud adjustment scheme while using the default (i.e., only anthropogenic) particle emissions similarly to Fountoukis et al. (2012). Table 1 summarizes the simulations reported in this study. Figure 1 shows the arithmetic mean number concentration over May 2008 at ground level for each PMCAMx-UF grid cell for particles larger than $10\left(N_{10}\right), 50\left(N_{50}\right)$, and $100 \mathrm{~nm}$ $\left(N_{100}\right)$ and all particles $\left(N_{\text {tot }}\right)$ as predicted using the baseline simulation ACDC-TUV-DE. The first 2 days of the simulation were excluded from the analysis to minimize the impact of the initial conditions on the results. The domain mean during May 2008 for $N_{\text {tot }}$ is $59200 \mathrm{~cm}^{-3}$; for $N_{10}$ the corresponding number is $7100 \mathrm{~cm}^{-3}$, for $N_{50} 1300 \mathrm{~cm}^{-3}$, and for $N_{100} 360 \mathrm{~cm}^{-3}$. The spatial pattern of the predicted number concentrations is similar to the results reported by Fountoukis et al. (2012), which were obtained using the simulation Napari-RADM-DE. The highest number concentrations are predicted over eastern Europe during this photochemically active period, while the lowest particle number concentrations are predicted over Nordic countries. The simulation Napari-TUV-DE predicts the domain mean of $N_{\text {tot }}, N_{10}$, $N_{50}$, and $N_{100}$ of $8100,4000,1500$, and 410 , respectively. Although updating the NPF scheme of PMCAMx-UF with ACDC-based formation rates significantly affects the number of small particles with diameter below $10 \mathrm{~nm}$, the spatial concentration remains unchanged. Updating the model cloudiness scheme by implementing the TUV radiative-transfer module did not greatly affect the spatial distribution of number concentrations but caused a minor change in the number concentration values. This is confirmed by the arithmetic domain mean values during May 2008 of $N_{\text {tot }}, N_{10}, N_{50}$ and $N_{100}$ predicted by the ACDC-RADM-DE simulation, which are $62000,6800,1200$ and $340 \mathrm{~cm}^{-3}$, respectively, and thus very similar to the baseline simulation. Including the natural particle emissions (in simulation ACDC-TUV-NE) resulted in $48300,6200,1300$ and $380 \mathrm{~cm}^{-3}$ for $N_{\text {tot }}, N_{10}, N_{50}$ and
$N_{100}$, respectively, therefore predicting lower number concentrations of small particles (i.e., diameter $<10 \mathrm{~nm}$ ) compared to those predicted by the baseline simulation. This is probably due to the higher sink of newly formed particles caused by the added natural particle emissions.

Figure 2 shows scatterplots of the predicted (ACDC-TUVDE) vs. measured hourly averaged $N_{10}, N_{50}$, and $N_{100}$ at the seven EUSAAR measurement sites during May 2008. The prediction-skill metrics of the simulations presented in Table 1 as compared with surface observations are summarized in Supplement Table S1. The model generally tends to overpredict the $N_{10}$ (normalized mean bias (NMB) $=126 \%$ for the base simulation), and the predicted $N_{10}$ are subject to scatter (normalized mean error $(\mathrm{NME})=145 \%$ for the base simulation) (see Table $\mathrm{S} 1$ for all the simulations). The reason for this overprediction is most likely linked to the missing condensable vapors and particle growth mechanisms in the simulations reported here (see Fountoukis et al., 2012; Ahlm et al., 2013; Patoulias et al., 2015). At most of the measurement sites, the predicted $N_{50}$ is in fairly good agreement with the observations, with about $70 \%$ of the data points falling within a factor of 2 of the measurements except for two sites: Mace Head (56\%) and Hyytiälä (59\%) (see Fig. 2 for the base simulation). The $N_{50}$ predictions are overall slightly biased (NMB $=-18 \%$ for the base simulation) but subject to scatter (NME $=41 \%$ for the base simulation). The predicted $N_{100}$ are more biased (NMB $=-45 \%$ ) and scattered $(\mathrm{NME}=51 \%)$ compared with $N_{50}$. Overall, the model performance is comparable to that reported by Fountoukis et al. (2012) and between the five simulations conducted here, with largest differences observed for the smallest particles if the scaled Napari scheme is used (see Table S1): linear correlation coefficients for monthly average concentrations throughout the domain between the different simulation cases and the ACDC-TUV-DE range from 0.827 (for $N_{\text {tot }}$ for Napari-TUV-DE vs. the base case) to 0.999 (for $N_{\text {tot }}$ and $N_{100}$ for ACDC-RADM-DE vs. the base case). As expected, including the natural emissions resulted in better agreement with the observations as compared with the de- 

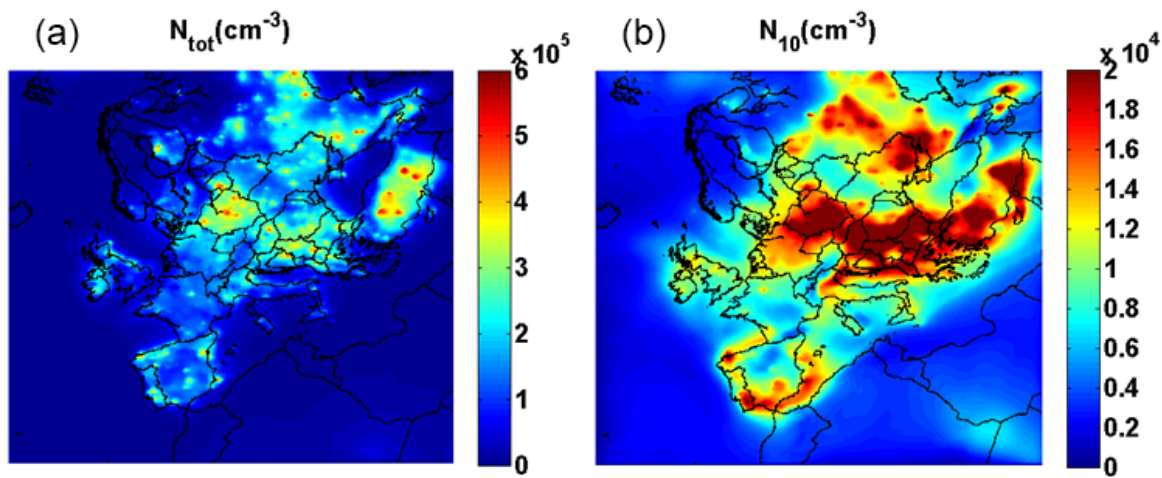
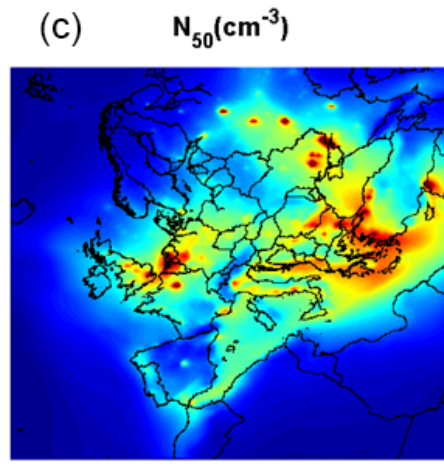

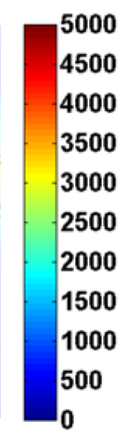

(d) $\quad \mathrm{N}_{100}\left(\mathrm{~cm}^{-3}\right)$

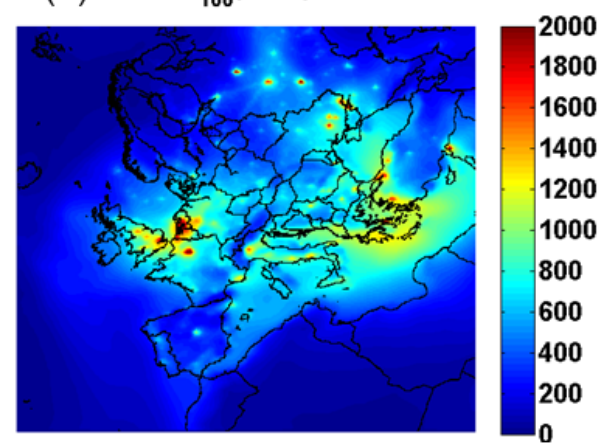

Figure 1. The simulated spatial distribution of the arithmetic mean of ground-level number concentration during May 2008 for particles larger than (a) $0.8 \mathrm{~nm}\left(N_{\text {tot }}\right)$, (b) $10 \mathrm{~nm}\left(N_{10}\right)$, (c) $50 \mathrm{~nm}\left(N_{50}\right)$, and (d) $100 \mathrm{~nm}\left(N_{100}\right)$. The PMCAMx-UF baseline simulation ACDC-TUV-DE is used (see Table 1). Note that different color bar scales are used for the different size ranges for readability.
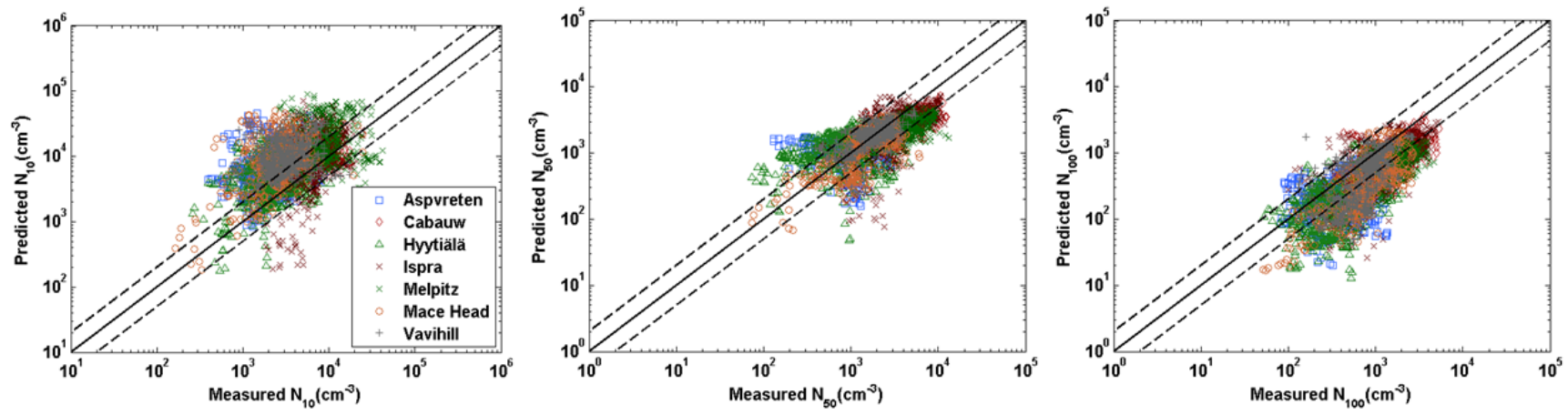

Figure 2. Comparison of predicted vs. measured hourly averaged number concentration of particles larger than $10 \mathrm{~nm}\left(N_{10}\right), 50 \mathrm{~nm}\left(N_{50}\right)$, and $100 \mathrm{~nm}\left(N_{100}\right)$ during May 2008 from the seven EUSAAR measurement stations during the EUCAARI project. Lines corresponding to $1: 1$ (solid line) and $1: 2$ and 2:1 (dashed lines) are shown. The PMCAMx-UF model simulation ACDC-TUV-DE is used (see Table 1).

fault case, especially for the small sizes (see Table S1 for comparison between ACDC-TUV-NE and ACDC-TUV-DE).

The biases presented here and in the following figures can thus be considered conservative estimates. Furthermore, in this study we have only considered the ternary sulfuric acid-water-ammonia particle formation scheme. There may be other significant mechanisms present, e.g., sulfuric acidamine particle formation (Bergman et al., 2015), with a geographical pattern resembling that of our results. Both mechanisms depend on sulfuric acid concentration predictions, which may be inaccurate as well. We compared the modeled and measured acid concentrations at one of the measurement sites (Melpitz) and found that the modeled concentrations were slightly overpredicted (Fig. S2 in the Supplement). This may also contribute to the overprediction of the small particle sizes. 

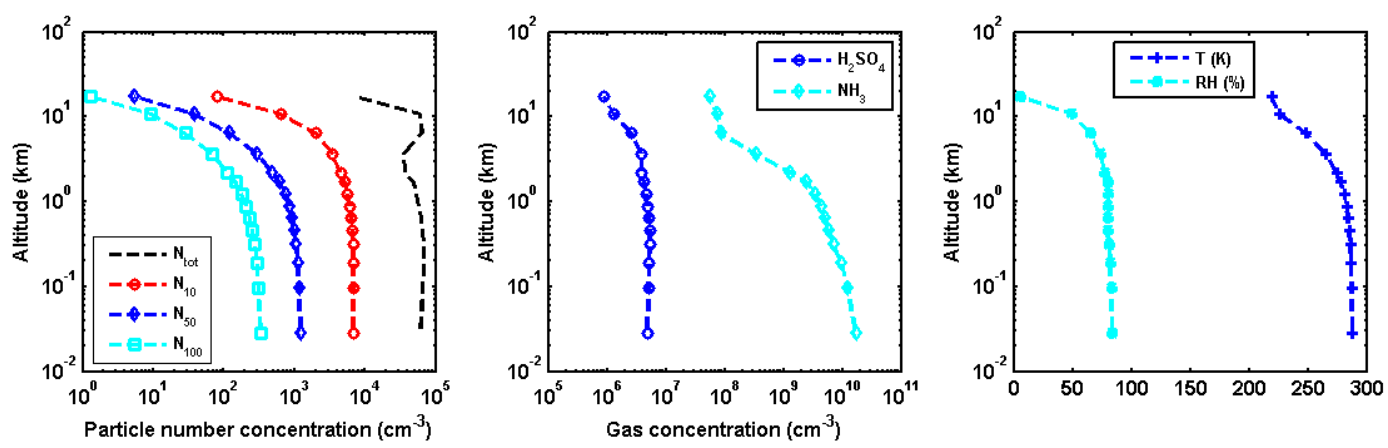

Figure 3. Vertical profiles of simulated variables averaged (arithmetic mean) over May 2008 and the whole simulation domain. Left panel: number concentration $\left(\mathrm{cm}^{-3}\right)$ of particles larger than $0.8 \mathrm{~nm}\left(N_{\text {tot }}\right), 10 \mathrm{~nm}\left(N_{10}\right), 50 \mathrm{~nm}\left(N_{50}\right)$, and $100 \mathrm{~nm}\left(N_{100}\right)$. Middle panel: gasphase concentration $\left(\mathrm{cm}^{-3}\right)$ of sulfuric acid $\left(\mathrm{H}_{2} \mathrm{SO}_{4}\right)$ and ammonia $\left(\mathrm{NH}_{3}\right)$. Right panel: temperature $(\mathrm{K})$ and relative humidity $(\%)$. The PMCAMx-UF baseline simulation ACDC-TUV-DE is used (see Table 1).

\subsection{Vertical profiles of particle number concentrations}

In this section we investigate the vertical distribution of the means of $N_{\text {tot }}, N_{10}, N_{50}$, and $N_{100}$ along with parameters relevant for predicting NPF for the base case simulations (Fig. 3). These parameters include gas-phase concentrations of $\mathrm{H}_{2} \mathrm{SO}_{4}, \mathrm{NH}_{3}, \mathrm{RH}$, and $T$. In the results shown in Fig. 3 the TUV radiation scheme has been used, thus representing the baseline simulation ACDC-TUV-DE. As can be seen from Fig. 3, particles smaller than $10 \mathrm{~nm}$ contribute significantly to the total number concentration throughout the tropospheric column, $N_{\text {tot }}$ is about 1 order of magnitude greater than $N_{10}$ and 2 and 3 orders of magnitudes greater than $N_{50}$ and $N_{100}$, respectively. Values of $N_{10}, N_{50}$, and $N_{100}$ decrease monotonically with altitude, dropping significantly at approximately $1 \mathrm{~km}$ (layers $6-8$ of the model). The vertical distribution of $N_{\text {tot }}$ shows a different trend at higher altitudes, where a bump in $N_{\text {tot }}$ occurs at around $6-11 \mathrm{~km}$, although no significant increase in the gas-phase concentrations of $\mathrm{H}_{2} \mathrm{SO}_{4}$ and $\mathrm{NH}_{3}$ are predicted at these altitudes (Fig. 3). The increase in $N_{\text {tot }}$ is mostly due to a significantly decreased coagulation sink for the newly formed particles, as the number of larger particles dramatically decreases with altitude, and partly due to the rapidly decreasing temperature. PMCAMxUF predicts the particle formation rates to decrease rapidly from around $2 \mathrm{~km}$ upward. The temperature, $\mathrm{RH}$, and sulfuric acid profile have similar relative trends to the $N_{10}, N_{50}$, and $N_{100}$ profiles. There is a plateau in temperature and $\mathrm{RH}$ (at the temperature range $285-288 \mathrm{~K}$ and $\mathrm{RH}$ range $80-83 \%$ ) profile up to altitude $1.2 \mathrm{~km}$. Above this altitude, however, the $\mathrm{RH}$ and temperature values decrease rapidly. The sharp decreases in the relative humidity, temperature, and particle number concentrations are consistent with the location of the boundary layer height. This is in agreement with Ferrero et al. (2010), who showed that mixing height estimations (over the city of Milan) derived from particle number concentration, temperature, and relative humidity are correlated with one another.
Figure 4 shows the comparison of the two simulations ACDC-TUV-DE and Napari-TUV-DE (see Table 1) with the observational data collected during the EUCAARILONGREX campaign measured by German DLR Falcon 20 and the British FAAM BAe-146 aircraft. The overall statistics of the comparisons between the modeled concentrations in all the simulations using the TUV radiation scheme and the aircraft data are presented in Supplement Table S2. The model using the ACDC-based formation rates predicts the number concentration profile of particles larger than $4 \mathrm{~nm}$ $\left(N_{4}\right)$ within about 1 order of magnitude of the observed $N_{4}$ profile throughout the atmospheric column. The scaled Napari NPF scheme leads to $N_{4}$ concentrations closer to the observations than those using the ACDC scheme with biases less than $50 \%$. As mentioned above, the vertical profiles presented in Fig. 4 are produced by the model using the TUV radiation scheme. A similar analysis of the vertical profiles using the RADM radiation scheme (simulation ACDC-RADM$\mathrm{DE}$ ), which is not shown here, results in exactly the same shape of the number concentration profiles. The vertical profiles using the RADM radiation scheme show minimal, yet worse, difference in the absolute number concentrations from the observations compared to the TUV radiation scheme. The number concentrations of particles larger than $10 \mathrm{~nm}\left(N_{10}\right)$ predicted by the model using the scaled Napari NPF scheme agree well with the observations throughout the atmospheric column (NMB less than $20 \%$; see Table S2). The model using the ACDC formation rates tends to overpredict the $N_{10}$ profile (NMB between 173 and 249\%). The shape of the observed $N_{10}$ vertical profile is captured throughout the atmospheric column regardless of the NPF scheme used. Both model versions have almost the same performance for the $N_{160-1040}$ profile within the boundary layer; both simulations (i.e., ACDC-TUV-DE and Napari-TUV-DE) underpredict the $N_{160-1040}$ profile by about a factor of 5 . This behavior is seen in the $N_{160-1040}$ profile corresponding to both observational data sets (i.e., Falcon 20, Fig. 4d, and BAe-146, Fig. 4e air- 

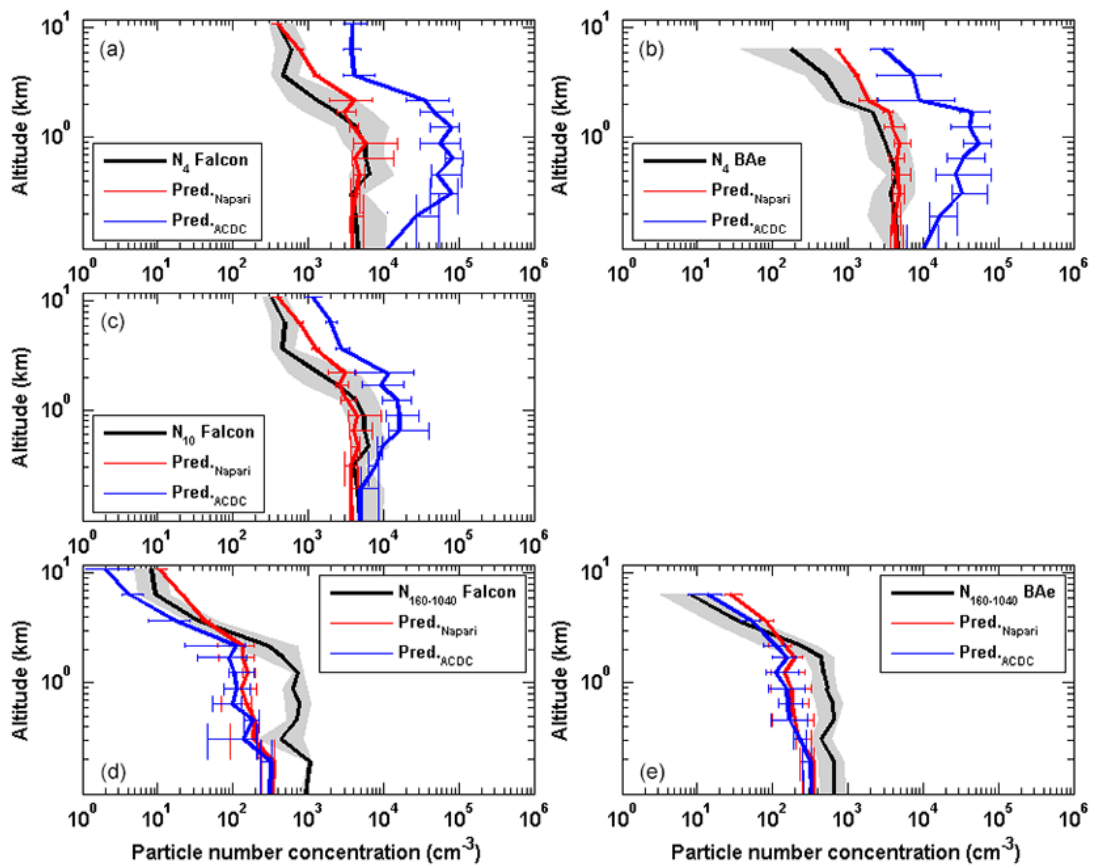

Figure 4. Vertical profiles of measured (black) and predicted (red and blue) particle number concentrations for the following size ranges: (a, b) larger than $4 \mathrm{~nm}\left(N_{4}\right)$ measurements collected by Falcon and BAe-146, respectively; (c) larger than $10 \mathrm{~nm}\left(N_{10}\right)$ measurements collected by Falcon 20; and (d, e) 160-1040 nm ( $\left.N_{160-1040}\right)$ measurements collected by Falcon and BAe-146, respectively, during May 2008. Red and blue lines show the predicted particle number concentrations by the PMCAMx-UF model using ACDC-based formation rates (ACDCTUV-DE) and scaled Napari new-particle formation scheme (Napari-TUV-DE), respectively. The lines show the median values of data points within each model layer, and the error bars and grey shading indicate the values between 25th and 75th percentiles of the model results and observations, respectively. Concentrations are given at ambient temperature and pressure.

craft data). This is at least partly due to the lack of sources of organic condensable vapors to grow the particles to larger sizes in the model (Patoulias et al., 2015), which will be investigated in a future study. The underprediction decreases for all model versions at altitudes above the boundary layer, improving the agreement with observational data.

The results for the model using the ACDC-based formation rates are comparable to previous studies. For example, Reddington et al. (2011) tested different NPF parameterizations in the $\mathrm{BL}$ - including activation, kinetic, and combined organic- $\mathrm{H}_{2} \mathrm{SO}_{4}$ parameterizations - which are implemented in the Global Model of Aerosol Processes (GLOMAP). The evaluation of the modeled vertical profiles of particle number concentrations against the aircraft measurements showed that all of the mentioned NPF schemes dramatically underpredicted particles in nucleation (NMB varies from -33 to -96 ) and Aitken-mode sizes $(-44<\mathrm{NMB}<-59)$. The larger particles $\left(N_{100}\right)$, however, were generally well captured by the model. Furthermore, Lupascu et al. (2015) compared simulated number concentrations with aircraft measurements collected during the Carbonaceous Aerosol and Radiative Effects Study (CARES) campaign. They also tested different NPF parameterizations including activation, kinetic, and combined organic- $\mathrm{H}_{2} \mathrm{SO}_{4}$ parameterizations, which are implemented in the regional-scale model WRF-Chem (Weather
Research and Forecasting) one at a time using a sectional framework to simulate the NPF. They found that their simulations overpredicted the particle number concentrations, especially in the smallest sizes (normalized mean bias of 126$608 \%$ for $N_{3}$ and $N_{10}$ ). The nucleation scheme had very little impact on the magnitude of the $\mathrm{CCN}$-sized particle number concentrations.

\subsection{Effect of the radiative-transfer scheme on predictions of particle number concentrations}

Updating the radiative-transfer scheme to the TUV scheme has a small effect on the predicted number concentrations; the vertical profile of the relative difference $\left(N_{\mathrm{TUV}}-\right.$ $\left.N_{\text {RADM }}\right) \times 100 / N_{\text {RADM }}$ in the May 2008 domain mean particle number concentrations shows a maximum reduction of about $-5.5 \%$ in $N_{\text {tot }}$ (at altitude $2.2 \mathrm{~km}$ ) and a maximum increase of about $9 \%$ in $N_{100}$ (at altitude range $0.7-2.2 \mathrm{~km}$ ). Figure 5 shows the spatial distribution of the absolute difference of the $\mathrm{H}_{2} \mathrm{SO}_{4}$ gas-phase concentration and total particle number concentrations between the simulations ACDCTUV-DE and ACDC-RADM-DE (see Table 1) at 12:00 UTC on 5 May 2008. Figure 5 also presents the cloud optical depth fields to illustrate the link between the cloud fields and changes in the particle number concentrations due to the new 

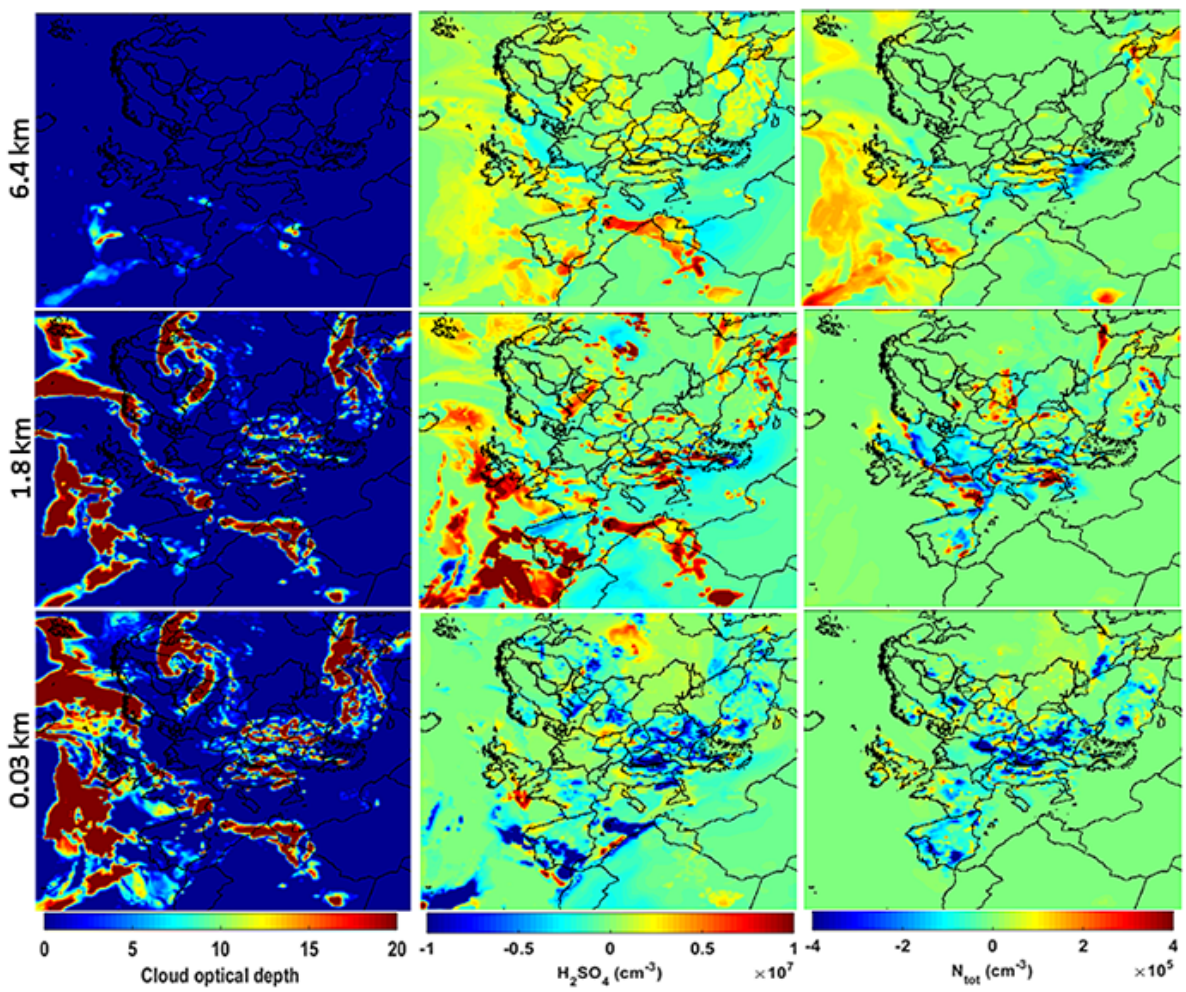

Figure 5. Left column: the total cloud optical depth supplied by the WRF meteorology model. Middle column: the absolute difference between the predictions using the TUV (the simulation ACDC-TUV-DE; see Table 1) and RADM (the simulation ACDC-RADM-DE) radiative-transfer schemes within PMCAMx-UF for $\mathrm{H}_{2} \mathrm{SO}_{4}$ concentration. Right column: absolute difference between prediction using TUV and RADM schemes for total particle number concentrations $N_{\text {tot }}$. The parameters shown in the figure are snapshots on 5 May 2008 at 12:00 UTC at model layers 1 (midpoint altitude: $0.03 \mathrm{~km}$ ), 9 (midpoint altitude: $1.7 \mathrm{~km}$ ), and 12 (midpoint altitude: $6.4 \mathrm{~km}$ ).

cloud adjustment scheme. The TUV scheme results in higher particle formation rates above and in the vicinity of the cloudy regions due to enhanced radiation and sulfuric acid production. This is in agreement with observations reported by Wehner et al. (2015). They concluded that the cloudy regions provide a favorable environment for NPF above and at the edges of clouds due to enhanced upward spectral irradiance and cloud-reflected spectral radiance around them. Sulfuric acid concentration is reduced below cloud in the TUV scheme, due to the enhanced UV attenuation scaling down the photolysis rates. However, as pointed out above, the effect on the total particle number concentrations is generally small.

\section{Conclusions}

We have updated the new-particle formation scheme within PMCAMx-UF with particle formation rates for the ternary $\mathrm{H}_{2} \mathrm{SO}_{4}-\mathrm{NH}_{3}-\mathrm{H}_{2} \mathrm{O}$ pathway simulated by the Atmospheric Cluster Dynamics Code using quantum chemical input data. The ACDC results were implemented in PMCAMx-UF as a lookup table from which the formation rates were interpolated. We believe this is the first time that reasonable par- ticle concentrations have been produced in a large-scale atmospheric model with a NPF scheme without any scaling factors or location/condition-dependent semi-empiricism. In addition to the updated NPF description, we have also updated PMCAMx-UF treatment of the cloudiness effect on the photolysis rates (i.e., cloud adjustment scheme) profile by implementing a streamlined version of the Tropospheric Ultraviolet and Visible radiative-transfer model (Madronich, 2002).

We used the updated PMCAMx-UF to simulate particle number concentration during May 2008 over Europe. During this period, the EUCAARI campaign was performed to measure the particle number size distributions within the atmospheric boundary layer at various European Supersites for Atmospheric Aerosol Research in addition to higher-altitude data collected by two research aircraft during the LONGREX campaign. Comparing the measured particle number concentrations at the EUSAAR sites to the predictions of the updated PMCAMx-UF shows that the model slightly overpredicts concentrations for particles with diameters between 10 and $100 \mathrm{~nm}$. Particles larger than $100 \mathrm{~nm}$ are slightly underpredicted. For details of the model performance statistics, the reader is referred to Supplement Tables S1 and S2. 
Vertical profiles of particle number concentrations show that predicted concentrations of small particles are within 1 order of magnitude of the aircraft measurements. The predicted Aitken- and accumulation-mode number concentrations are in quite good agreement with the observational data throughout the atmospheric column, while the concentrations of smaller particles are somewhat overpredicted by the ACDC-based NPF scheme. Including organic condensation onto the ultrafine particles could improve these predictions.

\section{Data availability}

The updated modules are freely available through contacting the corresponding author (ilona.riipinen@aces.su.se). The ACDC-based lookup table is available online at http://www. aces.su.se/research/research-facilities/models/.

\section{The Supplement related to this article is available online at doi:10.5194/gmd-9-2741-2016-supplement.}

Acknowledgements. We gratefully acknowledge Oona KupiainenMäättä for providing the ACDC-simulation data and generating the lookup table. Tinja Olenius is acknowledged for discussions and technical support related to ACDC, Radovan Krejci for providing the EUCAARI-LONGREX data, and Samuel Lowe for comments on the language. Falcon measurements and data analysis were funded by EUCAARI project no. 036833-2 and by DLR. The UK aircraft experiment was supported through EUCAARI and the UK Natural Environment Research Council through the APPRAISE programme, grant NE/E01108X/1. The authors also thank the Academy of Finland Centre of Excellence Programme (project number 272041), the Nordic Centre of Excellence CRAICC, Academy of Finland, ERC-StG-ATMOGAIN (278277) and ERCStG_MOCAPAF (257360).

Edited by: A. B. Guenther

Reviewed by: two anonymous referees

\section{References}

Adams, P. J. and Seinfeld, J. H.: Predicting global aerosol size distributions in general circulation models, J. Geophys. Res., 107, 4370, doi:10.1029/2001JD001010, 2002.

Ahlm, L., Julin, J., Fountoukis, C., Pandis, S. N., and Riipinen, I.: Particle number concentrations over Europe in 2030: the role of emissions and new particle formation, Atmos. Chem. Phys., 13, 10271-10283, doi:10.5194/acp-13-10271-2013, 2013.

Almeida, J., Schobesberger, S., Kürten, A., Ortega, I. K., Kupiainen-Määttä, O., Praplan, A. P., Adamov, A., Amorim, A., Bianchi, F., Breitenlechner, M., David, A., Dommen, J., Donahue, N. M., Downard, A., Dunne, E., Duplissy, J., Ehrhart, S., Flagan, R. C., Franchin, A., Guida, R., Hakala, J., Hansel, A.,
Heinritzi, M., Henschel, H., Jokinen, T., Junninen, H., Kajos, M., Kangasluoma, J., Keskinen, H., Kupc, A., Kurtén, T., Kvashin, A. N., Laaksonen, A., Lehtipalo, K., Leiminger, M., Leppä, J., Loukonen, V., Makhmutov, V., Mathot, S., McGrath, M. J., Nieminen, T., Olenius, T., Onnela, A., Petäjä, T., Riccobono, F., Riipinen, I., Rissanen, M., Rondo, L., Ruuskanen, T., Santos, F. D., Sarnela, N., Schallhart, S., Schnitzhofer, R., Seinfeld, J. H., Simon, M., Sipilä, M., Stozhkov, Y., Stratmann, F., Tomé, A., Tröstl, J., Tsagkogeorgas, G., Vaattovaara, P., Viisanen, Y., Virtanen, A., Vrtala, A., Wagner, P. E., Weingartner, E., Wex, H., Williamson, C., Wimmer, D., Ye, P., Yli-Juuti, T., Carslaw, K. S., Kulmala, M., Curtius, J., Baltensperger, U., Worsnop, D. R., Vehkamäki, H., and Kirkby, J.: Molecular understanding of sulphuric acid-amine particle nucleation in the atmosphere, Nature, 502, 359-363, doi:10.1038/nature12663, 2013.

Asmi, A., Wiedensohler, A., Laj, P., Fjaeraa, A.-M., Sellegri, K., Birmili, W., Weingartner, E., Baltensperger, U., Zdimal, V., Zikova, N., Putaud, J.-P., Marinoni, A., Tunved, P., Hansson, H.C., Fiebig, M., Kivekäs, N., Lihavainen, H., Asmi, E., Ulevicius, V., Aalto, P. P., Swietlicki, E., Kristensson, A., Mihalopoulos, N., Kalivitis, N., Kalapov, I., Kiss, G., de Leeuw, G., Henzing, B., Harrison, R. M., Beddows, D., O’Dowd, C., Jennings, S. G., Flentje, H., Weinhold, K., Meinhardt, F., Ries, L., and Kulmala, M.: Number size distributions and seasonality of submicron particles in Europe 2008-2009, Atmos. Chem. Phys., 11, 5505-5538, doi:10.5194/acp-11-5505-2011, 2011.

Bergman, T., Laaksonen, A., Korhonen, H., Malila, J., Dunne, E. M., Mielonen, T., Lehtinen, K. E. J., Kühn, T., Arola, A., and Kokkola, H.: Geographical and Diurnal Features of AmineEnhanced Boundary Layer Nucleation J. Geophys. Res.-Atmos., 120, 9606-9624, 2015.

Carslaw, K. S., Lee, L. A., Reddington, C. L., Pringle, K. J., Rap, A., Forster, P. M., Mann, G. W., Spracklen, D. V., Woodhouse, M. T., Regayre, L. A., and Pierce, J. R.: Large contribution of natural aerosols to uncertainty in indirect forcing, Nature, 503, 67-71, doi:10.1038/nature12674, 2013.

Chang, J. S., Brost, R. A., Isaksen, I. S. A., Madronich, S., Middleton, P., Stockwell, W. R., and Walcek, C. J.: A threedimensional Eulerian acid deposition model: Physical concepts and formulation, J. Geophys. Res., 92, 14681-14700, doi:10.1029/JD092iD12p14681, 1987.

Cui, Z., Gadian, A., Blyth, A., Crosier, J., and Crawford, I.: Observations of the Variation in Aerosol and Cloud Microphysics along the $20^{\circ} \mathrm{S}$ Transect on 13 November 2008 during VOCALS-Rex, J. Atmos. Sci., 71, 2927-2943, doi:10.1175/JASD-13-0245.1, 2014.

Dal Maso, M., Kulmala, M., Lehtinen, K. E. J., Mäkelä, J. M., Aalto, P., and O'Dowd, C. D.: Condensation and coagulation sinks and formation of nucleation mode particles in coastal and boreal forest boundary layers, J. Geophys. Res., 107, PAR 2-1-PAR 2-10, doi:10.1029/2001JD001053, 2002.

Denier van der Gon, H. A. C., Visschedijk, A. J. H., Johansson, C., Hedberg Larsson, E., Harrison, R., and Beddows, D.: Size resolved pan European anthropogenic particle number inventory, EUCAARI Deliverable report D141 (available on request from EUCAARI project office), TNO, the Netherlands, 2009.

Emery, C., Jung, J., Johnson, J., Yarwood, G., and Boyer, D.: Improving cloud impacts on photolysis using an on-line radiation 
model in CAMx, presented at the 9th Annual CMAS Conference, 11-13 October 2010, Chapel Hill, NC, USA, 2010.

Fahey K. M. and Pandis, S. N.: Optimizing model performance: Variable size resolution in cloud chemistry modeling, Atmos. Environ., 35, 4471-4478, doi:10.1016/S1352-2310(01)00224-2, 2001.

Feldpausch, P., Fiebig, M., Fritzsche, L., and Petzold, A.: Measurement of ultrafine aerosol size distributions by a combination of diffusion screen separators and condensation particle counters, J. Aerosol Sci., 37, 577-597, doi:10.1016/j.jaerosci.2005.04.009, 2006.

Ferrero, L., Perrone, M. G., Petraccone, S., Sangiorgi, G., Ferrini, B. S., Lo Porto, C., Lazzati, Z., Cocchi, D., Bruno, F., Greco, F., Riccio, A., and Bolzacchini, E.: Vertically-resolved particle size distribution within and above the mixing layer over the Milan metropolitan area, Atmos. Chem. Phys., 10, 3915-3932, doi:10.5194/acp-10-3915-2010, 2010.

Fiebig, M., Stein, C., Schroder, F., Feldpausch, P., and Petzold, A.: Inversion of data containing information on the aerosol particle size distribution using multiple instruments, J. Aerosol Sci., 36, 1353-1372, doi:10.1016/j.jaerosci.2005.01.004, 2005.

Fountoukis, C., Racherla, P. N., Denier van der Gon, H. A. C., Polymeneas, P., Charalampidis, P. E., Pilinis, C., Wiedensohler, A., Dall'Osto, M., O'Dowd, C., and Pandis, S. N.: Evaluation of a three-dimensional chemical transport model (PMCAMx) in the European domain during the EUCAARI May 2008 campaign, Atmos. Chem. Phys., 11, 10331-10347, doi:10.5194/acp11-10331-2011, 2011.

Fountoukis, C., Riipinen, I., Denier van der Gon, H. A. C., Charalampidis, P. E., Pilinis, C., Wiedensohler, A., O’Dowd, C., Putaud, J. P., Moerman, M., and Pandis, S. N.: Simulating ultrafine particle formation in Europe using a regional CTM: contribution of primary emissions versus secondary formation to aerosol number concentrations, Atmos. Chem. Phys., 12, 86638677, doi:10.5194/acp-12-8663-2012, 2012.

Fuzzi, S., Baltensperger, U., Carslaw, K., Decesari, S., Denier van der Gon, H., Facchini, M. C., Fowler, D., Koren, I., Langford, B., Lohmann, U., Nemitz, E., Pandis, S., Riipinen, I., Rudich, Y., Schaap, M., Slowik, J. G., Spracklen, D. V., Vignati, E., Wild, M., Williams, M., and Gilardoni, S.: Particulate matter, air quality and climate: lessons learned and future needs, Atmos. Chem. Phys., 15, 8217-8299, doi:10.5194/acp-15-8217-2015, 2015.

Gaydos, T. M., Stanier, C. O., and Pandis, S. N.: Modelling of in situ ultrafine atmospheric particle formation in the eastern United States, J. Geophys. Res., 110, D07S12, doi:10.1029/2004JD004683, 2005.

Gaydos, T. M., Pinder, R., Koo, B., Fahey, K., Yarwood, G., and Pandis, S. N.: Development and application of a three-dimensional aerosol chemical transport model, PMCAMx, Atmos. Environ., 41, 2594-2611, doi:10.1016/j.atmosenv.2006.11.034, 2007.

Guenther, A., Karl, T., Harley, P., Wiedinmyer, C., Palmer, P. I., and Geron, C.: Estimates of global terrestrial isoprene emissions using MEGAN (Model of Emissions of Gases and Aerosols from Nature), Atmos. Chem. Phys., 6, 3181-3210, doi:10.5194/acp-63181-2006, 2006.

Hamburger, T., McMeeking, G., Minikin, A., Birmili, W., Dall'Osto, M., O’Dowd, C., Flentje, H., Henzing, B., Junninen, H., Kristensson, A., de Leeuw, G., Stohl, A., Burkhart, J. F.,
Coe, H., Krejci, R., and Petzold, A.: Overview of the synoptic and pollution situation over Europe during the EUCAARILONGREX field campaign, Atmos. Chem. Phys., 11, 10651082, doi:10.5194/acp-11-1065-2011, 2011.

Hamburger, T., McMeeking, G., Minikin, A., Petzold, A., Coe, H., and Krejci, R.: Airborne observations of aerosol microphysical properties and particle ageing processes in the troposphere above Europe, Atmos. Chem. Phys., 12, 11533-11554, doi:10.5194/acp-12-11533-2012, 2012.

Henschel, H., Navarro, J. C. A., Yli-Juuti, T., Kupiainen-Määttä, O., Olenius, T., Ortega, I. K., Clegg, S. L., Kurtén, T., Riipinen, I., and Vehkamäki, H.: Hydration of atmospherically relevant molecular clusters: Computational chemistry and classical thermodynamics. J. Phys. Chem. A., 118, 2599-2611, doi:10.1021/jp500712y, 2014.

Henschel, H., Kurtén, T., and Vehkamäki, H.: Computational Study on the Effect of Hydration on New Particle Formation in the Sulfuric Acid/Ammonia and Sulfuric Acid/Dimethylamine Systems, J. Phys. Chem. A, 120, 18861896, doi:10.1021/acs.jpca.5b11366, 2016.

Jen, C. N., McMurry, P. H., and Hanson, D. R.: Stabilization of sulfuric acid dimers by ammonia, methylamine, dimethylamine, and trimethylamine, J. Geophys. Res., 119, 7502-7514, doi:10.1002/2014JD021592, 2014.

Jung, J., Adams, P. J., and Pandis, S. N.: Simulating the size distribution and chemical composition of ultrafine particles during nucleation events, Atmos. Environ., 40, 2248-2259, doi:10.1016/j.atmosenv.2005.09.082, 2006.

Jung, J., Fountoukis, C., Adams, P. J., and Pandis, S. N.: Simulation of in situ ultrafine particle formation in the eastern United States using PMCAMx-UF, J. Geophys. Res., 115, D03203, doi:10.1029/2009JD012313, 2010.

Jung, J. G., Pandis, S. N., and Adams, P. J.: Evaluation of nucleation theories in a sulfur-rich environment, Aerosol Sci. Technol., 42, 495-504, doi:10.1080/02786820802187085, 2008.

Karydis, V. A., Tsimpidi, A. P., and Pandis, S. N.: Evaluation of a three-dimensional chemical transport model (PMCAMx) in the eastern United States for all four seasons, J. Geophys. Res., 112, D14211, doi:10.1029/2006JD007890, 2007.

Kerminen, V.-M., Paramonov, M., Anttila, T., Riipinen, I., Fountoukis, C., Korhonen, H., Asmi, E., Laakso, L., Lihavainen, H., Swietlicki, E., Svenningsson, B., Asmi, A., Pandis, S. N., Kulmala, M., and Petäjä, T.: Cloud condensation nuclei production associated with atmospheric nucleation: a synthesis based on existing literature and new results, Atmos. Chem. Phys., 12, 1203712059, doi:10.5194/acp-12-12037-2012, 2012.

Kirkby, J., Curtius, J., Almeida, J., Dunne, E., Duplissy, J., Ehrhart, S., Franchin, A., Gagné, S., Ickes, L., Kürten, A., Kupc, A., Metzger, A., Riccobono, F., Rondo, L., Schobesberger, S., Tsagkogeorgas, G., Wimmer, D., Amorim, A., Bianchi, F., and Breitenlechner, M.: Role of sulphuric acid, ammonia and galactic cosmic rays in atmospheric aerosol nucleation, Nature, 476, 429-433, doi:10.1038/nature10343, 2011.

Kirkby, J., Duplissy, J., Sengupta, K., Frege, C., Gordon, H., Williamson, C., Heinritzi, M., Simon, M., Yan, C., Almeida, J., Tröstl, J., Nieminen, T., Ortega, I. K., Wagner, R., Adamov, A., Amorim, A., Bernhammer, A., Bianchi, F., Breitenlechner, M., Brilke, S., Chen, X., Craven, J., Dias, A., Ehrhart, S., Flagan, R. C., Franchin, A., Fuchs, C., Guida, R., Hakala, J., Hoyle, C. 
R., Jokinen, T., Junninen, H., Kangasluoma, J., Kim, J., Krapf, M., Kürten, A., Laaksonen, A., Lehtipalo, K., Makhmutov, V., Mathot, S., Molteni, U., Onnela, A., Peräkylä, O., Piel, F., Petäjä, T., Praplan, A. P., Pringle, K., Rap, A., Richards, N. A. D., Riipinen, I., Rissanen, M. P., Rondo, L., Sarnela, N., Schobesberger, S., Scott, C. E., Seinfeld, J. H., Sipilä, M., Steiner, G., Stozhkov, Y., Stratmann, F., Tomé, A., Virtanen, A., Vogel, A. L., Wagner, A. C., Wagner, P. E., Weingartner, E., Wimmer, D., Winkler, P. M., Ye, P., Zhang, X., Hansel, A., Dommen, J., Donahue, N. M., Worsnop, D. R., Baltensperger, U., Kulmala, M., Carslaw, K. S., and Curtius, J.: Ion-induced nucleation of pure biogenic particles, Nature, 533, 521-526, doi:10.1038/nature17953, 2016.

Korhonen, P., Kulmala, M., Laaksonen, A., Viisanen, Y., McGraw, R., and Seinfeld, J. H.: Ternary nucleation of $\mathrm{H}_{2} \mathrm{SO}_{4}, \mathrm{NH}_{3}$, and $\mathrm{H}_{2} \mathrm{O}$ in the atmosphere, J. Geophys. Res., 104, 26349-26353, doi:10.1029/1999JD900784, 1999.

Kulmala, M., Liisa, P., and Mäkelä, J. M.: Stable sulphate clusters as a source of new atmospheric particles, Nature, 404, 66-69, doi:10.1038/35003550, 2000.

Kulmala, M., Vehkamäki, H., Petäjä, T., Dal Maso, M., Lauri, A., Kerminen, V.-M., Birmili, W., and McMurry, P.H.: Formation and growth rates of ultrafine atmospheric particles: a review of observations, J. Aerosol Sci., 35, 143-176, doi:10.1016/j.jaerosci.2003.10.003, 2004.

Kulmala, M., Lehtinen, K. E. J., and Laaksonen, A.: Cluster activation theory as an explanation of the linear dependence between formation rate of $3 \mathrm{~nm}$ particles and sulphuric acid concentration, Atmos. Chem. Phys., 6, 787-793, doi:10.5194/acp-6-787-2006, 2006.

Kulmala, M., Asmi, A., Lappalainen, H. K., Carslaw, K. S., Pöschl, U., Baltensperger, U., Hov, Ø., Brenquier, J.-L., Pandis, S. N., Facchini, M. C., Hansson, H.-C., Wiedensohler, A., and O'Dowd, C. D.: Introduction: European Integrated Project on Aerosol Cloud Climate and Air Quality interactions (EUCAARI) - integrating aerosol research from nano to global scales, Atmos. Chem. Phys., 9, 2825-2841, doi:10.5194/acp-9-2825-2009, 2009.

Kulmala, M., Asmi, A., Lappalainen, H. K., Baltensperger, U., Brenguier, J.-L., Facchini, M. C., Hansson, H.-C., Hov, Ø., O'Dowd, C. D., Pöschl, U., Wiedensohler, A., Boers, R., Boucher, O., de Leeuw, G., Denier van der Gon, H. A. C., Feichter, J., Krejci, R., Laj, P., Lihavainen, H., Lohmann, U., McFiggans, G., Mentel, T., Pilinis, C., Riipinen, I., Schulz, M., Stohl, A., Swietlicki, E., Vignati, E., Alves, C., Amann, M., Ammann, M., Arabas, S., Artaxo, P., Baars, H., Beddows, D. C. S., Bergström, R., Beukes, J. P., Bilde, M., Burkhart, J. F., Canonaco, F., Clegg, S. L., Coe, H., Crumeyrolle, S., D’Anna, B., Decesari, S., Gilardoni, S., Fischer, M., Fjaeraa, A. M., Fountoukis, C., George, C., Gomes, L., Halloran, P., Hamburger, T., Harrison, R. M., Herrmann, H., Hoffmann, T., Hoose, C., Hu, M., Hyvärinen, A., Hõrrak, U., Iinuma, Y., Iversen, T., Josipovic, M., Kanakidou, M., Kiendler-Scharr, A., Kirkevåg, A., Kiss, G., Klimont, Z., Kolmonen, P., Komppula, M., Kristjánsson, J.-E., Laakso, L., Laaksonen, A., Labonnote, L., Lanz, V. A., Lehtinen, K. E. J., Rizzo, L. V., Makkonen, R., Manninen, H. E., McMeeking, G., Merikanto, J., Minikin, A., Mirme, S., Morgan, W. T., Nemitz, E., O’Donnell, D., Panwar, T. S., Pawlowska, H., Petzold, A., Pienaar, J. J., Pio, C., Plass-Duelmer, C., Prévôt, A. S. H., Pryor, S., Reddington, C. L., Roberts, G., Rosenfeld, D.,
Schwarz, J., Seland, Ø., Sellegri, K., Shen, X. J., Shiraiwa, M., Siebert, H., Sierau, B., Simpson, D., Sun, J. Y., Topping, D., Tunved, P., Vaattovaara, P., Vakkari, V., Veefkind, J. P., Visschedijk, A., Vuollekoski, H., Vuolo, R., Wehner, B., Wildt, J., Woodward, S., Worsnop, D. R., van Zadelhoff, G.-J., Zardini, A. A., Zhang, K., van Zyl, P. G., Kerminen, V.-M., S Carslaw, K., and Pandis, S. N.: General overview: European Integrated project on Aerosol Cloud Climate and Air Quality interactions (EUCAARI) - integrating aerosol research from nano to global scales, Atmos. Chem. Phys., 11, 13061-13143, doi:10.5194/acp11-13061-2011, 2011.

Laaksonen, A., Kulmala, M., Berndt, T., Stratmann, F., Mikkonen, S., Ruuskanen, A., Lehtinen, K. E. J., Dal Maso, M., Aalto, P., Petäjä, T., Riipinen, I., Sihto, S.-L., Janson, R., Arnold, F., Hanke, M., Ücker, J., Umann, B., Sellegri, K., O’Dowd, C. D., and Viisanen, Y.: $\mathrm{SO}_{2}$ oxidation products other than $\mathrm{H}_{2} \mathrm{SO}_{4}$ as a trigger of new particle formation. Part 2: Comparison of ambient and laboratory measurements, and atmospheric implications, Atmos. Chem. Phys., 8, 7255-7264, doi:10.5194/acp-8-7255-2008, 2008.

Liu, P. S. K., Leaitch, W. R., Strapp, J. W., and Wasey, M. A.: Response of Particle Measuring Systems Airborne ASASP and PCASP to $\mathrm{NaCl}$ and Latex Particles, Aerosol Sci. Technol., 16, 83-95, doi:10.1080/02786829208959539, 1992.

Lupascu, A., Easter, R., Zaveri, R., Shrivastava, M., Pekour, M., Tomlinson, J., Yang, Q., Matsui, H., Hodzic, A., Zhang, Q., and Fast, J. D.: Modeling particle nucleation and growth over northern California during the 2010 CARES campaign, Atmos. Chem. Phys., 15, 12283-12313, doi:10.5194/acp-15-12283-2015, 2015.

Madronich, S.: Tropospheric ultraviolet and visible radiation model, National Center for Atmospheric Research, Boulder, Colorado, USA, available at: https://www2.acom.ucar.edu/modeling/ tropospheric-ultraviolet-and-visible-tuv-radiation-model (last access: March 2014), 2002.

Makkonen, R., Asmi, A., Korhonen, H., Kokkola, H., Järvenoja, S., Räisänen, P., Lehtinen, K. E. J., Laaksonen, A., Kerminen, V.M., Järvinen, H., Lohmann, U., Bennartz, R., Feichter, J., and Kulmala, M.: Sensitivity of aerosol concentrations and cloud properties to nucleation and secondary organic distribution in ECHAM5-HAM global circulation model, Atmos. Chem. Phys., 9, 1747-1766, doi:10.5194/acp-9-1747-2009, 2009.

Matsui, H., Koike, M., Kondo, Y., Takegawa, N., Wiedensohler, A., Fast, J. D., and Zaveri, R. A.: Impact of new particle formation on the concentrations of aerosols and cloud condensation nuclei around Beijing, J. Geophys. Res., 116, D19208, doi:10.1029/2011JD016025, 2011.

Matsui, H., Koike, M., Takegawa, N., Kondo, Y., Takami, A., Takamura, T., Yoon, S., Kim, S.-W., Lim, H.-C., and Fast, J. D.: Spatial and temporal variations of new particle formation in East Asia using an NPF-explicit WRF-chem model: North-south contrast in new particle formation frequency, J. Geophys. Res.Atmos., 118, 11647-11663, doi:10.1002/jgrd.50821, 2013.

McMurry, P.: Photochemical aerosol formation from $\mathrm{SO}_{2}$ : A theoretical analysis of smog chamber data, J. Colloid Interf. Sci., 78, 513-527, doi:10.1016/0021-9797(80)90589-5, 1980.

Merikanto, J., Zapadinsky, E., Lauri, A., and Vehkamäki, H.: Origin of the Failure of Classical Nucleation Theory: Incorrect Description of the Smallest Clusters, Phys. Rev. Lett., 98, 145702, doi:10.1103/PhysRevLett.98.145702, 2007a. 
Merikanto, J., Napari, I., Vehkamäki, H., Anttila, T., and Kulmala, M.: New parameterization of sulfuric acid-ammonia-water ternary nucleation rates at tropospheric conditions, J. Geophys. Res., 112, D15207, doi:10.1029/2006JD007977, 2007 b.

Merikanto, J., Spracklen, D. V., Mann, G. W., Pickering, S. J., and Carslaw, K. S.: Impact of nucleation on global CCN, Atmos. Chem. Phys., 9, 8601-8616, doi:10.5194/acp-9-8601-2009, 2009.

Napari, I., Noppel, M., Vehkamäki, H., and Kulmala, M.: Parametrization of ternary nucleation rates for $\mathrm{H}_{2} \mathrm{SO}_{4}-\mathrm{NH}_{3}-\mathrm{H}_{2} \mathrm{O}$ vapors, J. Geophys. Res., 107, 4381, doi:10.1029/2002JD002132, 2002.

O’Dowd, C. D., Langmann, B., Varghese, S., Scannell, C., Ceburnis, D., and Facchini, M. C.: A combined organic-inorganic sea-spray source function, Geophys. Res. Lett., 35, L01801, doi:10.1029/2007GL030331, 2008.

Olenius, T., Kupiainen-Määttä, O., Ortega, I. K., Kurtén, T., and Vehkamäki, H.: Free energy barrier in the growth of sulfuric acid-ammonia and sulfuric acid-dimethylamine clusters, J. Chem. Phys., 139, 084312, doi:10.1063/1.4819024, 2013.

Ortega, I. K., Kupiainen, O., Kurtén, T., Olenius, T., Wilkman, O., McGrath, M. J., Loukonen, V., and Vehkamäki, H.: From quantum chemical formation free energies to evaporation rates, Atmos. Chem. Phys., 12, 225-235, doi:10.5194/acp-12-225-2012, 2012.

Paasonen, P., Nieminen, T., Asmi, E., Manninen, H. E., Petäjä, T., Plass-Dülmer, C., Flentje, H., Birmili, W., Wiedensohler, A., Hõrrak, U., Metzger, A., Hamed, A., Laaksonen, A., Facchini, M. C., Kerminen, V.-M., and Kulmala, M.: On the roles of sulphuric acid and low-volatility organic vapours in the initial steps of atmospheric new particle formation, Atmos. Chem. Phys., 10, 11223-11242, doi:10.5194/acp-10-11223-2010, 2010.

Patoulias, D., Fountoukis, C., Riipinen, I., and Pandis, S. N.: The role of organic condensation on ultrafine particle growth during nucleation events, Atmos. Chem. Phys., 15, 6337-6350, doi:10.5194/acp-15-6337-2015, 2015.

Pierce, J. R. and Adams, P. J.: A computationally efficient aerosol nucleation/condensation method: pseudo-steadystate sulfuric acid, Aerosol Sci. Tech., 43, 216-226, doi:10.1080/02786820802587896, 2009.

Reddington, C. L., Carslaw, K. S., Spracklen, D. V., Frontoso, M. G., Collins, L., Merikanto, J., Minikin, A., Hamburger, T., Coe, H., Kulmala, M., Aalto, P., Flentje, H., Plass-Dülmer, C., Birmili, W., Wiedensohler, A., Wehner, B., Tuch, T., Sonntag, A., O'Dowd, C. D., Jennings, S. G., Dupuy, R., Baltensperger, U., Weingartner, E., Hansson, H.-C., Tunved, P., Laj, P., Sellegri, K., Boulon, J., Putaud, J.-P., Gruening, C., Swietlicki, E., Roldin, P., Henzing, J. S., Moerman, M., Mihalopoulos, N., Kouvarakis, G., Ždímal, V., Zíková, N., Marinoni, A., Bonasoni, P., and Duchi, R.: Primary versus secondary contributions to particle number concentrations in the European boundary layer, Atmos. Chem. Phys., 11, 12007-12036, doi:10.5194/acp-11-12007-2011, 2011.

Sihto, S.-L., Kulmala, M., Kerminen, V.-M., Dal Maso, M., Petäjä, T., Riipinen, I., Korhonen, H., Arnold, F., Janson, R., Boy, M., Laaksonen, A., and Lehtinen, K. E. J.: Atmospheric sulphuric acid and aerosol formation: implications from atmospheric measurements for nucleation and early growth mechanisms, Atmos. Chem. Phys., 6, 4079-4091, doi:10.5194/acp-6-4079-2006, 2006.
Skamarock, W. C., Klemp, J. B., Dudhia, J., Gill, D. O. Barker, D. M., and Wang, W.: A Description of the Advanced Research WRF Version 2, NCAR Technical Note, doi:10.5065/D6DZ069T, 2005.

Sofiev, M., Vankevich, R., Lanne, M., Koskinen, J., and Kukkonen, J.: On integration of a Fire Assimilation System and a chemical transport model for near-real-time monitoring of the impact of wild-land fires on atmospheric composition and air quality, Modelling, Monitoring and Management of Forest Fires, WIT Trans. Ecol. Envir., 119, 343-351, 2008a.

Sofiev, M., Lanne, M., Vankevich, R., Prank, M., Karppinen, A., and Kukkonen, J.: Impact of wild-land fires on European air quality in 2006-2008, Modelling, Monitoring and Management of Forest Fires, WIT Trans. Ecol. Envir., 119, 353-361, 2008b.

Spracklen, D. V., Carslaw, K. S., Kulmala, M., Kerminen, V.-M., Mann, G. W., and Sihto, S.-L.: The contribution of boundary layer nucleation events to total particle concentrations on regional and global scales, Atmos. Chem. Phys., 6, 5631-5648, doi:10.5194/acp-6-5631-2006, 2006.

Takemura, T., Nakajima, T., Dubovik, O., Holben, B. N., and Kinne, S.: Single scattering albedo and radiative forcing of various aerosol species with a global threedimensional model, J. Climate, 15, 333352, doi:10.1175/15200442(2002)015<0333:SSAARF>2.0.CO;2, 2002.

Vehkamäki, H., Kulmala, M., Napari, I., Lehtinen, K. E. J., Timmreck, C., Noppel, M., and Laaksonen, A.: An improved parameterization for sulfuric acid-water nucleation rates for tropospheric and stratospheric conditions, J. Geophys. Res., 107, 4622, doi:10.1029/2002JD002184, 2002.

Visschedijk, A. J. H., Zandveld, P., and Denier van der Gon, H. A. C.: A high resolution gridded European emission database for the EU integrated project GEMS, TNO Report 2007 A R0233/B, Netherlands, Organization for Applied Scientific Research, 2007.

Wehner, B., Werner, F., Ditas, F., Shaw, R. A., Kulmala, M., and Siebert, H.: Observations of new particle formation in enhanced UV irradiance zones near cumulus clouds, Atmos. Chem. Phys., 15, 11701-11711, doi:10.5194/acp-15-11701-2015, 2015.

Westervelt, D. M., Pierce, J. R., and Adams, P. J.: Analysis of feedbacks between nucleation rate, survival probability and cloud condensation nuclei formation, Atmos. Chem. Phys., 14, 55775597, doi:10.5194/acp-14-5577-2014, 2014.

Yu, F.: Effect of ammonia on new particle formation: A kinetic $\mathrm{H}_{2} \mathrm{SO}_{4}-\mathrm{H}_{2} \mathrm{O}-\mathrm{NH}_{3}$ nucleation model constrained by laboratory measurements, J. Geophys. Res., 111, D01204, doi:10.1029/2005JD005968, 2006.

Yu, F. and Luo, G.: Simulation of particle size distribution with a global aerosol model: contribution of nucleation to aerosol and CCN number concentrations, Atmos. Chem. Phys., 9, 76917710, doi:10.5194/acp-9-7691-2009, 2009.

Yu, F., Luo, G., Bates, T. S., Anderson, B., Clarke, A., Kapustin, V., Yantosca, R. M., Wang, Y., and Wu, S.: Spatial distributions of particle number concentrations in the global troposphere: Simulations, observations, and implications for nucleation mechanisms, J. Geophys. Res., 115, D17205, doi:10.1029/2009JD013473, 2010.

Zhang, Y., McMurry, P. H., Yu, F., and Jacobson, M. Z.: A comparative study of nucleation parameterizations: 1. Examination and evaluation of the formulations, J. Geophys. Res., 115, D20212, doi:10.1029/2010JD014150, 2010. 